IRSH 56 (20I I), Special Issue, pp. I4I-I64 doi:I0.1017/S002085901 1000423 (C) 20 I I Internationaal Instituut voor Sociale Geschiedenis

\title{
Jewish Ethics and Women's Work in the Late Medieval and Early Modern Arab-Islamic World
}

\author{
K A R IN H OFMEESTER \\ Internationaal Instituut voor Sociale Geschiedenis \\ E-mail: kho@iisg.nl
}

SummarY: In this article, Moses Maimonides' interpretation of Jewish law on women and work - as reflected in his Mishneh Torah - is contrasted with the daily lives of Jewish working women as portrayed in the documents of the Cairo Geniza. Later rabbinic writings and European travel accounts are analysed to show how Jewish ethics of women and work were translated into social practice in the late medieval and early modern Arab-Islamic world, where Islamic law and the existence of separate worlds for men and women rather than the contrast between public and private spheres seem to have informed general ideas about women and work.

\section{INTRODUCTION}

There is no shortage of Jewish texts containing laws and rules on women and work, but finding sources that tell us how those theoretical ethics were applied in practice is more difficult. For the late medieval and the early modern world, however, we have a number of sources that can be contrasted: Maimonides' Mishneb Torah, a central text of Jewish ethics, and the documents found in the Cairo Geniza give a wonderful insight into the daily lives of Jews in the Arab-Islamic world. This article intends to show how Maimonides interpreted Jewish law and how his interpretation affected - and contrasted with - the working lives of Jewish women in the late medieval and early modern Arab-Islamic world. ${ }^{I}$ Since the Cairo Geniza documents cover the period up to the sixteenth century, we shall look at other sources, such as rabbinic writings and European travel accounts, to show how Jewish ethical thinking on women and work was translated into social practice in an Islamic environment.

I. S.D. Goitein, who analysed many of the Geniza documents in his seminal six-volume work, A Mediterranean Society: The Jewish Communities of the Arab World as Portrayed in the Documents of the Cairo Geniza (Berkeley, CA [etc.], 1967-1993), speaks of the Arab world. Though this article will also discuss Jews in the Ottoman Empire - which included parts of Europe - we shall use the term "Arab-Islamic world". 


\section{THE WORLD OF MOSES MAIMONIDES AND HIS WORKS}

Moses Maimonides was born in I 135 in Cordoba, the main centre of Jewish culture, which flourished in Islamic Spain, especially in the tenth and eleventh centuries. He studied the Torah, philosophy, law, and the exact sciences, reading the works of Greek philosophers as well as of Muslim scholars. Maimonides and his family left Cordoba when the Almohades, a strict orthodox Berber Muslim dynasty, conquered the city in II 48 and threatened the Jewish community with the choice of conversion to Islam, death, or exile. The family subsequently settled in different places in Spain, ending up in Fez, Morocco, in about I I60. In I 66 they settled in Fustat (Old Cairo), where Moses would become nagid, the official leader of the Jewish community recognized by the caliphate. ${ }^{2}$ After the Fatimid conquest of Egypt and the foundation of Cairo as the caliph's seat of government in 972 , the city had become the political, economic, and cultural centre of the Islamic world. ${ }^{3}$ By about the time of Maimonides's arrival in Egypt the less tolerant Sunni Ayyubid dynasty had taken over, although the position of Jews in the city was left largely untouched. Estimates of the number of Jews in Cairo in that period vary from I, 500 to 4,000 , at the most making up less than I per cent of the total population. ${ }^{4}$

Other important Jewish communities in the Arab-Islamic world at the time were Alexandria and Rosetta (Rashid), Gaza, Jerusalem, Safed, Damascus, Aleppo, Baghdad, and Basra, as well as Tripoli, Fez, and Tunis. Members of the rather small upper layer of the mostly urban Jewish communities worked as government officials, doctors, judges, and leading businessmen, the next layer being smaller businessmen, professionals, including master artisans, followed by urban craftsmen and labourers, and finally the peasants.' Like other religious and ethnic communities,

2. For biographical information on Moses Maimonides, see Joel L. Kraemer, "Moses Maimonides: An Intellectual Portrait", in Kenneth Seeskin (ed.), The Cambridge Companion to Maimonides (Cambridge, 2005), pp. 10-57; idem, Maimonides: The Life and World of One of Civilization's Greatest Minds (New York, 2008); and Mark R. Cohen, "Maimonides' Egypt", in Eric L. Ormsby (ed.), Moses Maimonides and His Time (Washington DC, 1989), pp. 2 I-34. 3. The Fatimid caliphate was an Arab Shi'a caliphate that ruled over varying areas of the Maghreb, Sicily, Malta, and the Levant from 909 to I I 7 I. The caliphate was characterized by a relative degree of tolerance of Jews and Christians. For the position of Jews in Egypt in the period, see Norman A. Stillman, "The Non-Muslim Communities: The Jewish Community", in Carl F. Petry (ed.), The Cambridge History of Egypt, I: Islamic Egypt, 640-I517 (Cambridge, 1998), pp. 198-2 го.

4. Cohen, "Maimonides' Egypt", p. 24, for the Jewish population. See also E. Ashtor, The Jews and the Mediterranean Economy 10th-15th Centuries (London, 1983), p. 20. For the total population of Cairo, see Kevin Shillington, Encyclopedia of African History (New York, 2005), p. 199 .

5. Goitein, A Mediterranean Society: The Jewish Communities of the Arab World, I: Economic Foundations (Berkeley, CA [etc.], I967), pp. 75-79. 
Jews specialized in certain professions: they were prominent in the textile industry, above all in silks and dyeing, while the production of glass and metalwork, especially silversmithing, were Jewish specializations. Finally, many Jews were engaged in the food industry and the production of chemicals for medicinal purposes. ${ }^{6}$

Next to his work as physician and community leader - though partly in sabbatical periods from the latter function - Maimonides wrote extensive medical texts and works on Jewish philosophy and law. His most famous philosophical work is the Guide for the Perplexed, in which he tried to reconcile Aristotelian ideas about reason and knowledge with the teachings of the Torah. His most important work on Jewish law is the code Mishneb Torah, literally meaning "The Second Law", intended to be a summary of the entire body of Jewish religious law. ${ }^{7}$ Whereas earlier codes had followed the Talmud's sometimes haphazard arrangement, with only very few attempts to improve on that order, Maimonides classified by topic scattered statements into groups of laws. ${ }^{8}$ The main goal of the codification was to facilitate and simplify the law to make it accessible and comprehensible. ${ }^{9}$ Also, Maimonides felt that, in comparison with the level of intellectual life in Spain, Jews in the Arab world had left themselves with too little knowledge of Jewish law: "in our days, severe vicissitudes prevail, and all feel the pressure of hard times. The wisdom of our wise men has disappeared; the understanding of our prudent men is hidden." ${ }^{\circ}$

Maimonides considered Mishneb Torab his life's work and spent almost ten years (II68-II77) writing and revising it. Though Mishneb Torab was not the final codification, it was very influential among the Jewish communities in the Arab-Islamic world and it became a benchmark for subsequent writing on Jewish law. The Shulchan Aruch, a codification written in the sixteenth century by Rabbi Joseph Caro, is a more or less widely accepted codification of practical Jewish law, and his rules are in part based upon Maimonides' rules as formulated in the Mishneb Torah. ${ }^{\text {II }}$

6. Idem, "The Main Industries of the Mediterranean Area as Reflected in the Records of the Cairo Geniza", Journal of the Economic and Social History of the Orient, 4:2 (I96I), pp. I67-197, г7г.

7. Jewish law, halakha, constitutes the practical application of the $6 \mathrm{I}_{3}$ mitzvot (commandments) in the Torah (the five books of Moses, the "Written Law"), and as developed through discussion and debate in the classical rabbinic literature, especially the Mishnah ("Oral Law") and the Talmud.

8. Kraemer, "Moses Maimonides: An Intellectual Portrait", p. 36. See also Isadore Twersky, Introduction to the Code of Maimonides (Mishneh Torab) (New Haven, CT [etc.], 1980).

9. Kraemer, "Moses Maimonides: An Intellectual Portrait", p. 27.

Io. Cohen, "Maimonides' Egypt", p. 29.

I I. Jewish Encyclopedia, available at: http://www.jewishencyclopedia.com/view.jsp?artid= I 88\&letter $=$ C\#668; last accessed s December 2010. 
To illustrate Maimonides' authority, one of his translators stated "From Moses to Moses, none arose like Moses". ${ }^{22}$

\section{MISHNEHTORAH ON WOMEN AND WORK}

The Mishneb Torah consists of fourteen books, subdivided into sections, chapters, and paragraphs. One of the books is entitled On Women (Nashim), which deals with laws mainly of marriage, divorce, and conduct between men and women. In Nashim, Maimonides follows the Talmud on women and work, which says "her food against the work of her hands". That sentence, which in essence means that a husband should provide his wife with food and clothing, and in return she should give him her earnings, plays a very important role in the perception of paid work done by married women within Jewish work ethics. ${ }^{13}$ Maimonides more or less repeats the sentence, stating: "a wife's earnings are chargeable against her maintenance", ${ }^{14}$ which means that women were expected to work, to earn an income, and to hand that income over to their husbands.

Rabbinic literature, written roughly between the second and fifth centuries, gives us some insight into the ideas behind the rule. It teaches that study of the Torah is perceived as the primary means of understanding God's will for the world, and therefore it is the highest spiritual activity in which a man can participate. Preferably, men should study the Torah full-time and it was regarded as unseemly that they should at the same time be engaged in mundane occupations. In the "rabbinically imagined family income", as Gail Labovitz describes that utopian situation, the wives of Torah-studying men provided them with a livelihood. ${ }^{I 5}$ According to Labovitz, the rule that women should earn an income had all kinds of practical advantages for men. If men stayed in the study house all day, they could avoid undesirable contact with women on the shopfloor. Working for an income would protect women from idleness, which could lead either to lustfulness or to dull-mindedness, or - perhaps even worse - the wish to study the Torah themselves. ${ }^{16}$

I2. Norman Roth, "The Jews in Spain", in Ormsby, Moses Maimonides and His Time, pp. $\mathrm{I}-20,3$.

I3. Babylonian Talmud, ketubot $47 \mathrm{~b}$, quoted and explained in Goitein, A Mediterranean Society: The Jewish Communities of the Arab World, III: The Family (Berkeley, CA [etc.], 1978), p. I 32.

I4. The Code of Maimonides, Book IV, The Book of Women, translated from the Hebrew by Isaac Klein (New Haven, CT [etc.], I972), p. 74.

i s. For an elaborate analysis of these and other rabbinic texts see Gail Labovitz, "The Scholarly Life - The Labouring Wife: Gender, Torah and the Family Economy in Rabbinic Culture", NASHIM: A Journal of Jewish Women's Studies and Gender Issues, I 3 (2007), pp. 8-48. See also Miriam B. Peskowitz, Spinning Fantasies, Rabbis, Gender, History (Berkeley, CA [etc.], 1997). I6. Labovitz, "The Scholarly Life - The Labouring Wife", pp. Iо-I I, I9-20. Though Maimonides himself stated that women were exempted from Torah study, some rabbis felt that 
That argument could, of course, be turned on its head: who would generate a family's income if women were to start studying the Torah?

Returning to Maimonides' Mishneb Torah, we should stress that although several paragraphs in his work indicate that men should study the Torah as much as possible and should not pay too much attention to worldly affairs such as earning an income, he does not explicitly expect wives to provide a man's income. "Even if he is a poor person supported by charity and begging, and even if he had a wife and children, he still has to set aside time during the day and by night for Torah study". If men had to work for an income, they could still study the Torah: "Of the great Sages of Israel, some were woodcutters, others were water-fetchers [...]. Even so, they learnt Torah by day and by night". A man who had to work for an income should divide his time, and to give an example of Maimonides' ideals about the division: "If one had a profession at which one worked for three hours a day, and one learnt Torah for nine hours" ${ }^{17}$ Where the extra income would come from is not explained in Mishneb Torah, but probably the income of female family members played an important role in Maimonides' "imagined family income".

The idleness argument is a large part of Maimonides's motivation for allowing women to work. Even when a man was rich, a woman should do some gainful work: "she should not sit idle, without work, because idleness leads to immorality" " ${ }^{18}$ However, there were some exceptions to that rule: "if the wife says: 'I want neither your maintenance nor work', her wish must be respected and she may not be coerced". ${ }^{9}$

Apart from the work women performed to earn an income, there was also the unpaid work women had to do to serve their husbands and families. There were fixed tasks a woman had to perform, no matter how wealthy her husband nor how many maidservants they had. No maidservant could perform the intimate tasks of washing her husband's face, hands, and feet, pouring his cup for him, spreading his couch, and waiting on him. If the family was not wealthy enough for maidservants, a wife should "bake bread in the oven, cook food, wash clothes, nurse her child, put fodder before her husband's mount - but not before his cattle - and attend to the grinding of corn". ${ }^{20}$ Maimonides stated that a man was

women should be forbidden to study the Torah. For discussions of this question see ibid., pp. 30-3 I, and Kraemer, Maimonides, pp. 335-336.

I7. The Yale Judaica series edition of the Mishneh Torah provides an excellent translation of all but one of the fourteen works. The first book "On Knowledge" has not yet appeared in this series, so we have used an English translation available at http://www.panix.com/ jjbaker/ MadaTT.html; last accessed s December 2010.

18. Code of Maimonides: The Book of Women, p. I3 I.

19. Ibid., p. 74.

20. Ibid., p. I3 I. 
expected to demand such unpaid work of his wife: "If a man makes his wife vow to do no work at all, he must divorce her and pay her her kettubah, because idleness leads to immorality". ${ }^{21}$ Here, we can see that the idleness argument applied equally to her paid and unpaid work. Maimonides even added that if a wife refused "to perform any kind of work that she is obliged to do, [she] may be compelled to perform it, even by scourging her with a rod". ${ }^{22}$

Returning to the work women ought to perform to earn an income, an important question to be asked is: What type of work was considered appropriate for women according to Maimonides? Here, his answer is a typically Jewish one: it all depends on the custom of the country. ${ }^{23}$

Where the custom is for wives to weave, she must weave; to embroider, she must embroider; to spin wool or flax, she must spin. If it is not the custom of the women of that town to do all these kinds of work, he cannot compel her to do any of them, except spinning wool only - because flax injures the mouth and the lips - for spinning is a kind of work that is characteristic of women, as it is said, "And all women that were wise-hearted did spin with their hands". (Exodus, 35.25$)^{24}$

The next important question to be answered is: Where was a woman supposed to work, in private or public space? For that, the balakbic rules of zniut, modesty, were very influential. They determined the way a woman - especially a married woman - should dress and behave in public. One of the rules was that contact between a woman and a man other than her own husband or close relatives should be restricted to the minimum. In the application of that law, Maimonides once again points to local customs:

In a place where it is the custom for a woman to go out into the street wearing upon her head not only a cap, but to wear also a veil that covers her whole body like a cloak, he must include in the garments given to her a veil [...] in order that she might wear it to her father's house, to a house of mourning, or to a wedding feast. For every woman is entitled to go to her father's house to visit him, or to a house of mourning or a wedding feast as an act of kindness to her friends and relatives, in order that they in turn might visit her on similar occasions, for she is not in a prison where she cannot come and go. On the other hand, it is unseemly for a woman to be constantly going out abroad and into the streets, and the husband should prevent his wife from doing this and should not let her go out,

\section{Ibid.}

22. Ibid., p. I33. This rule, which seems to be at odds with Jewish ethics in general and Maimonides in particular, has led to an enormous amount of discussion. See Isaac Klein's introduction to his translation of The Book of Women, pp. xxxv-xxxvi, and Kraemer, Maimonides, pp. 343-346.

23. After the Babylonian conquest, the halakhic rule "dina de-malkhuta dina", meaning the law of the kingdom is the law (and is binding), was adopted; see Aryeh Shmuelevitz, The Jews of the Ottoman Empire in the Late Fifteenth and the Sixteenth Centuries (Leiden, 1984), pp. 42-43. 24. Code of Maimonides: The Book of Women, p. Izo. 


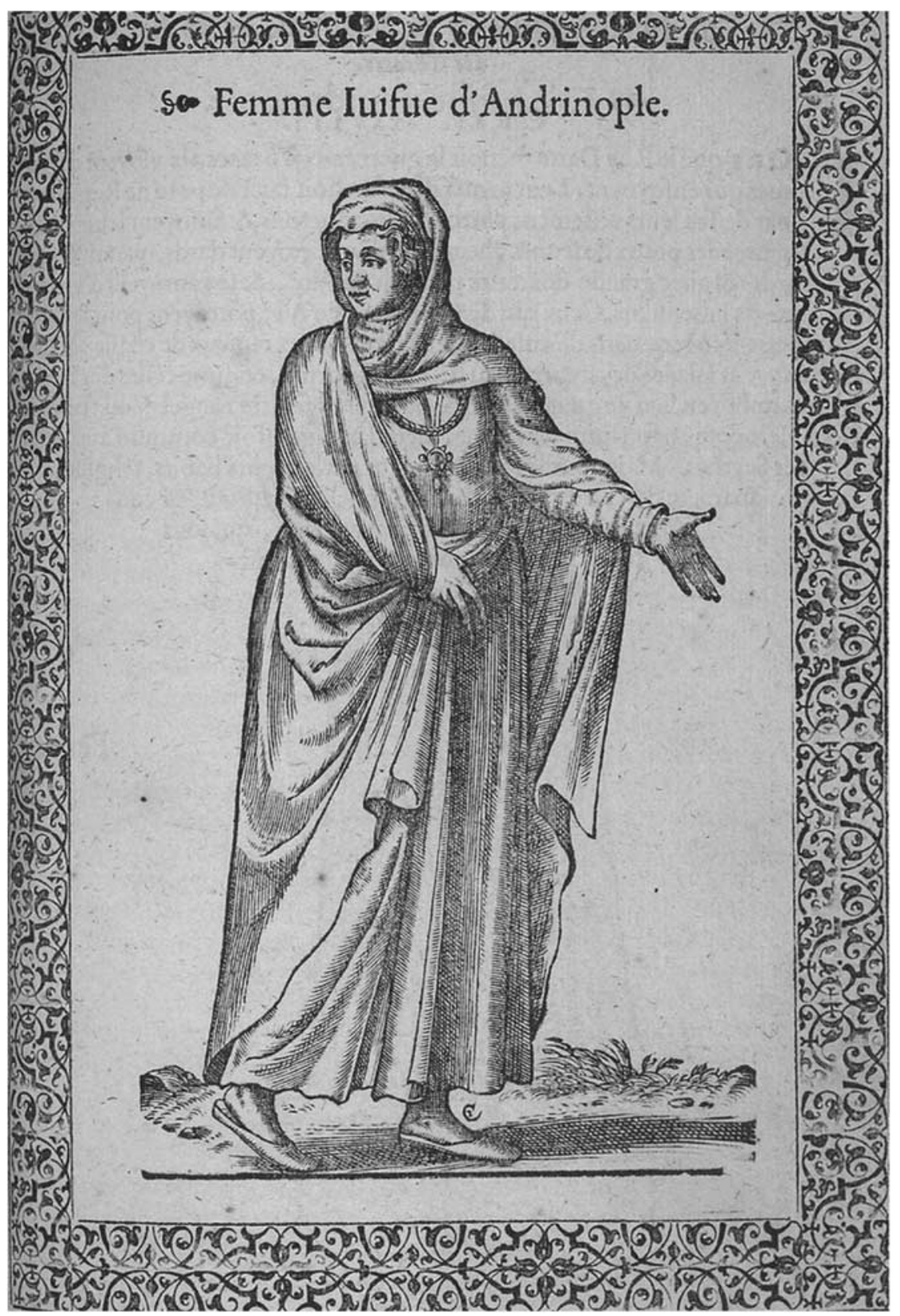

Figure I. Jewish woman from Edirne, c.I 500.

Nicolas de Nicolay, Discours et histoire véritable des navigations, pérégrinations et voyages, faicts en la Turquie (Antwerp, 1586). Volume in the collection of the Library of Congress. 
except for once or twice a month, as the need may arise. Rather, the seemly thing for a woman is to sit in the corner of her house, for so it is written "All glorious is the king's daughter within the palace" (Psalms, 45.I4). ${ }^{25}$

\section{SOCIAL PRACTICE AS REFLECTED IN MARRIAGE CONTRACTS}

Maimonides's judgments should be seen against the background of his position as a Jew in a Muslim society. Having dhimmi status, Jews, like all other non-Muslims who adhered to a monotheistic faith while living in Muslim countries, enjoyed relative protection and safety in return for the payment of a capital tax and obedience to certain rules concerning behaviour and dress. Apart from that legal arrangement, Jews in the medieval Arab-Islamic world were very much integrated into the surrounding culture, speaking the same language, reading the same philosophers, sharing intellectual discourse, Islamic codification, and poetry. ${ }^{26}$

For Jewish women, that meant a greater restriction on their freedom to move about than was experienced by their co-religionists in Christian Europe. There, women were active in a number of crafts, sold their products on the open market, and sometimes could even become members of a guild. ${ }^{27}$ One searches in vain in the Talmud for rules on the maximum number of times a woman can leave the house. ${ }^{28}$ According to Avraham Grossman, it is clear that Maimonides was led to his position by the influence of Muslim society, ${ }^{29}$ but there was a difference between rules and social practice. The Mishnab states that a woman may be divorced and will not receive her delayed instalment (see below): "if she goes out with her hair flowing loose; or if she spins in the market place; or if she talks with just anybody". ${ }^{\circ}$ That phrase shows that even the sages knew

25. Ibid., p. 83 .

26. For this integration, see Mark R. Cohen, "Medieval Jewry in the World of Islam", in Martin Goodman (ed.), The Oxford Handbook of Jewish Studies (Oxford, 2002), pp. 193-2 I 8, $202 \mathrm{ff}$. 27. Avraham Grossman, Pious and Rebellious: Jewish Women in Medieval Europe (Lebanon, NH, 2004), pp. II4-II7; Shulamith Shahar, The Fourth Estate: A History of Women in the Middle Ages (London [etc.], 1996), pp. I7I-I77. In the Arab-Islamic world women were listed from time to time in certain guilds, such as the Istanbul slave dealers in 1640 and flower-planters in 1778 and Edirne rosewater producers in c.1650, but these are exceptions; Fariba ZarinebafShahr, "The Role of Women in the Urban Economy of Istanbul, 1700-1850", International Labor and Working-Class History, 60 (200I), pp. I4I-I 52, I 42.

28. Mordechai A. Friedman, "The Ethics of Medieval Jewish Marriage", in S.D. Goitein (ed.), Religion in a Religious Age: Proceedings of Regional Conferences Held at the University of California, Los Angeles and Brandeis University in April, 1973 (Cambridge, MA, 1974), pp. 83-102, 92.

29. Grossman, Pious and Rebellious, p. Io5.

30. Jacob Neusner, The Mishnab: A New Translation (New Haven, CT [etc.], 1988), p. 392: Mishnah Ketubot 7.6. 
that practice was not always in accordance with theory, and even Maimonides himself admitted that it was sometimes wise not to follow the rules too strictly: "Pay regard to God by disregarding his law". ${ }^{3}$

For the history of the daily lives of Jewish communities in the ArabIslamic world, including the practical application of the laws, we have a wonderful, unprecedented source: the Cairo Geniza. According to Jewish law, pieces of sacred texts, such as fragments of the Torah containing God's name, should not be thrown away after use but should be buried in a Geniza (burial place). Normally, such a Geniza would be located in a cemetery; however, in Fustat the Geniza was located inside the synagogue. Called the Ben Ezra Synagogue, it was originally built as a Coptic church but at some time during the ninth century it was transformed into a synagogue. It still stands today, although it was heavily reconstructed in the late nineteenth century when the Geniza was discovered. Not only did it contain fragmented pages of religious texts adding up to threequarters of a million pages, it also comprised a variety of documents, written in Judeo-Arabic (Arabic in Hebrew characters) from everyday life, dating from the eleventh to the thirteenth centuries mostly. The documents vary from letters (business as well as private correspondence), court records, marriage contracts, deeds of divorce, wills, business documents, account books, to lists of people receiving charity, and so on. ${ }^{32}$

Marriage contracts, called ketuboth, are an important source for our purpose here. A ketubab is a pre-nuptial agreement, drawn up with the consent of bride and bridegroom, which outlines the rights and responsibilities of the groom in relation to the bride and very often also her obligations to him. It also contains the financial agreements they made. ${ }^{33}$ The ketubab mentions the gifts the bridegroom had to give to the bride, consisting of three parts: the traditional obligatory marriage gift, being a certain number of silver pieces or its equivalent in value; the additional gift, which was seen as the actual gift; as well as a delayed instalment the husband had to pay in the case of divorce, or which his heirs had to pay in case of his death. ${ }^{34}$ The ketubab includes the dowry the bride received from her parents and which was brought to the marriage. Often the dowry included a detailed list of items, but sometimes only the value was mentioned, and would typically consist of jewellery, clothing, and items

31. Goitein, A Mediterranean Society: The Jewish Communities of the Arab World, I: Economic Foundations, p. I 37 .

32. For a short description of the Geniza see Cohen, "Medieval Jewry in the World of Islam", pp. I96-i97.

33. For more information on the marriage contracts see Mordechai Akiva Friedman, Jewish Marriage in Palestine: A Cairo Geniza Study (Tel Aviv [etc.], 1980).

34. Goitein, A Mediterranean Society: The Jewish Communities of the Arab World, III: The Family, pp. I88ff. 
for the household such as bedding and copper utensils, but might also include entire houses or parts of them or other landed property. The dowry was usually many times greater than a husband's marriage gift. ${ }^{35}$

The rules on a husband's financial obligation were part of halakba; the dowry, however, was a matter of practical wisdom and local custom. Therefore, statements about it found in the Geniza ketuboth are not influenced by ancient law but reflect the real situation at the time. They are also changeable over time and space. ${ }^{36}$ Many hundreds of ketuboth were found in the Cairo Geniza. It is worth remembering that they ended up in the Geniza because the marriage was at least "discussed", otherwise the ketubah, often accompanied by court documents, would not have been kept there. The ketuboth cover the period from the tenth to the beginning of the sixteenth century. Many of them concern couples living in Fustat, but there are also ketuboth from other parts of Egypt, Syria (Damascus, Aleppo), Palestine (Jerusalem), Lebanon (Tyre), Algeria (Tinis), Libya (Barqa), and Tunisia (Qayrawan), so we may safely assume that the conclusions that can be drawn from the ketuboth are valid for a large proportion of the Jewish communities living in the Arab-Islamic world. The ketuboth are evenly spread over seven social classes, as defined by Goitein, varying from destitute to wealthy couples. ${ }^{37}$

For the economic position of women, it is important to consider the control over the possessions each of the partners brought to the marriage. Marriage gifts and dowries were potentially income-producing possessions: money could be lent against interest and houses could be let, or sold. For a woman, the disposal of her properties could enlarge her economic activities and independence if she could use the capital or real estate to earn money as a moneylender or estate agent. Maimonides states: "And the four things he is entitled to are all of Scribal origin, namely the following: he is entitled to her earnings, to anything she finds, and to the usufruct of her estate during her lifetime. And should she die in his lifetime, he is her heir." ${ }^{8}$

That meant that the economic power of a husband included his wife's dowry, since he had the right to any usufruct on it, but that power was limited by the obligation - extended to his heirs - to restore every penny of it in the case of divorce or his death. ${ }^{39}$ A wife could dispose of both the original and the additional portions of her marriage gift but not the

37. Ibid., pp. 95ff., and the appendix, p. 419.

38. Code of Maimonides: The Book of Women, p. 74.

39. Goitein, A Mediterranean Society: The Jewish Communities of the Arab World, III: The Family, pp. I80-I8I. In practice, it was often hard for widows to collect the debts owed them pursuant to their marriage contracts. See Mark R. Cohen, Poverty and Charity in the Jewish Community of Medieval Egypt (Princeton, NJ [etc.], 2005), pp. I40-I4I. 
delayed instalment, and of any gifts or inheritances that she received during her married life from her family. Such personal properties could be explicitly excluded from her husband's jurisdiction, ${ }^{4}{ }^{\circ}$ but he retained full jurisdiction over her dowry, which was worth many times more. Also, a wife's transactions, such as the purchase or sale of a house, had to be endorsed by her husband, thus limiting the economic freedom of women.

\section{FINDING WAYS OUT}

In practice, women found ways out of their restricted economic position. For the fifteenth and sixteenth centuries we have responsa literature that tells us more about social practice. Responsa were written "answers" from rabbis and other "decisors of Jewish law" on questions concerning specific halakbic matters. After their expulsion from Spain at the end of the fifteenth century, many Jewish exiles found their way to various countries, but chiefly to North Africa, the Balkans, and Palestine, where they met existing Jewish communities which observed different practices. As a result, disputes arose about a number of topics: the power a community could exercise over its members for example, but also about the way contracts and business dealings were handled. All such disputes had to be resolved in accordance with the principles of the halakba; therefore we see a lot of responsa from that period, written especially by rabbis from Spain.

From fifteenth-century responsa we know that women concealed commercial transactions from their husbands. ${ }^{4 \mathrm{I}}$ We know too that Jewish women appealed regularly to Muslim courts, especially on matters concerning legacies and inheritance. According to Islamic law a woman could keep her property and was allowed to manage it, and a separation of funds between husband and wife persisted throughout communal life. ${ }^{42} \mathrm{~A}$ woman's property rights included her dowry, gifts, and inheritances. ${ }^{43}$ According to one author, "sometimes a threat from a woman or her family to go to the kadi [a judge ruling in accordance with Islamic religious law] was all it took to make a husband change his behaviour and the rabbinic judges adopt a more flexible position on financial and personal matters". ${ }^{44}$ A common cause of marital dispute was a husband's management of the dowry. In practice, if conflicts

40. Goitein, A Mediterranean Society: The Jewish Communities of the Arab World, III: The Family, p. I79.

4I. Maya Shatzmiller, Labour in the Medieval Islamic World (Leiden [etc.], 1994), p. 364.

42. Ibid.

43. Idem, Her Day in Court: Women's Property Rights in Fifteenth-Century Granada (Cambridge, MA, 2007), p. 3 .

44. Ruth Lamdan, "Levant: Women in the Jewish Communities after the Ottoman Conquest of I5I7", in Jewish Women: A Comprehensive Historical Encyclopedia. Available at Jewish Women's Archive: http://jwa.org/encyclopedia/article/levant-women-in-jewish-communitiesafter-ottoman-conquest-of-i 5 I7; last accessed 5 December 2010. 
really got out of hand, a husband usually gave up control of and responsibility for his wife's dowry, handing it all over to her. ${ }^{45}$ If a widow or divorcee remarried, she often stipulated in her ketubab that she could keep control of her possessions, "even if she threw them into the Dead Sea". ${ }^{6}$ Women not only disputed control of their potentially income-yielding properties, they also tried to circumvent the rule that a woman must hand over her own income, as we can see from changes in the rules relating to women's income as reflected in the ketuboth.

Remarks on working women with an income are very rare in tenthand eleventh-century ketuboth but become more frequent in twelfth- and thirteenth-century contracts. ${ }^{47}$ Twelfth-century requests have been found addressed to the leader of the Jewish community to the effect that the ketubah should include the sentences "that he should under no circumstances demand from his spouse her earnings, and, if she worked, they belonged to her", and "the husband has no right to his wife's earnings, but she has to buy her own clothing from her earnings". ${ }^{8}$ In the thirteenth century such remarks about the earnings of women had become a regular feature. Fixed formulas such as "the work of her hands against her clothing" appear frequently in contracts, and there are surviving statements from husbands renouncing the right to their brides' earnings. ${ }^{49}$ According to Goitein,

Most marriage documents from the Mamluk period (I250-I I I7) contain a reference to the wife's work. Not only widows and divorcées, or poor women, but also brides with a large trousseau would stipulate the retention of their earnings and free their spouses from the obligation of providing them with clothing. ${ }^{5 \circ}$

How can we explain the tendency towards more income-earning women, and in which professions did they work?

\section{WOMEN'S WORK AND LABOUR RELATIONS: 1500 AND 1650}

During the first centuries of the Islamic era, far-reaching political, social, and economic changes had taken place in the Arab world which had changed the lives of its inhabitants, including the Jews. The changes transformed the inhabitants into a primarily urban people who began to

45. Goitein, A Mediterranean Society: The Jewish Communities of the Arab World, III: The Family, pp. I 8 I-I 82.

46. Ruth Lamdan, A Separate People: Jewish Women in Palestine, Syria and Egypt in the Sixteenth Century (Leiden, 2000), pp. I I4-I I 5.

47. Goitein, A Mediterranean Society: The Jewish Communities of the Arab World, III: The Family, p. I 32.

48. Ibid., pp. I32-1 33 .

49. Ibid., pp. I33-1 34 .

50. Ibid., p. I 34 . 


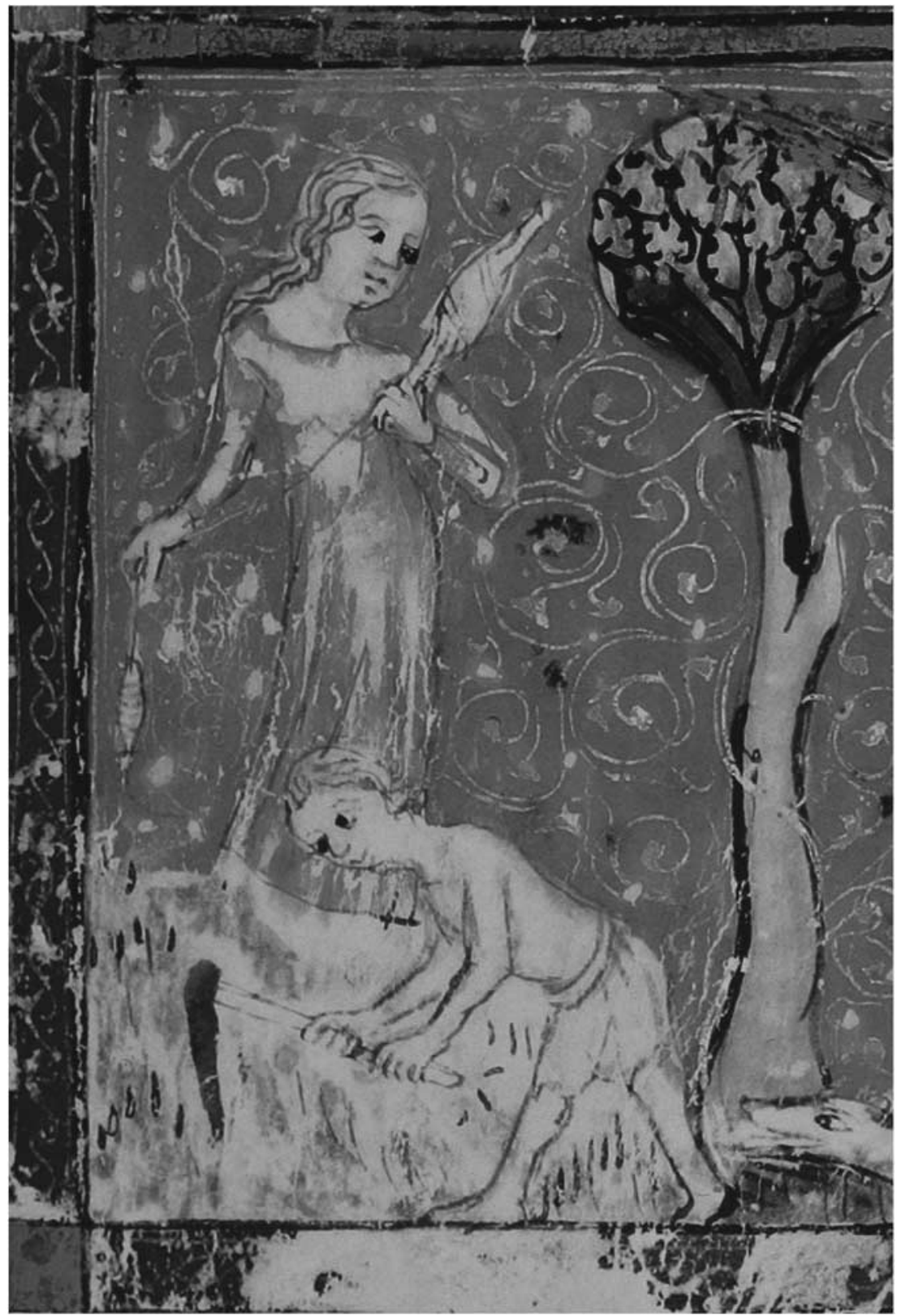

Figure 2. Woman spinning, detail from the Sarajevo Haggadah. A Haggadah is a religious text that sets out the order of the Passover Seder. The Sarajevo Haggadah was commissioned and created in Barcelona, Spain, around 1350.

National Museum of Bosnia and Herzegovina, Sarajevo. Haggadah, folio 3 verso (lower register, detail). Used with permission. 
take part in the commercial revolution, spurred by laissez-faire Fatimid

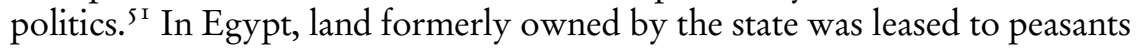
and wage labourers, while slave labour was not only no longer the core of the agricultural labour force, through urbanization and the reorganization of labour in urban centres its importance to manufacturing too was diminished. Productivity in rural areas rose because of the transition, which led to increased availability of raw materials for use by manufacturing industry in the cities, especially for the textile industry, which boomed. As a consequence, more female wage labour entered the textile industry, and evidence from the late medieval period indicates that from the tenth century to the fifteenth century women's participation in the labour force increased in towns, where it came to dominate the textile industry by monopolizing certain tasks such as spinning, dyeing, and embroidery.

The textile industry subsequently became the largest, most specialized, and most market-oriented industry in Muslim cities. ${ }^{52}$ Goitein cautiously suggests that the increasing number of remarks about female wage labour in the ketuboth of the thirteenth century might be explained by a deterioration in the economic situation and the impoverishment of the population, something which did indeed occur during the Ayyubid and subsequent Mamluk rule. ${ }^{53}$ One might also suggest that as women's wage labour increased, ethical debates about it expanded and finally found their way into the ketuboth. Maya Shatzmiller adds another argument to this and suggests that the formulas referred to above found their way into Jewish marriage contracts as a result of the increasing influence of Islamic law, where a woman's wage labour was seen as one of her property rights, to which she was entitled absolutely. ${ }^{54}$ What we can state safely is that with the transition from slave labour to free wage labour the number of women performing free waged labour increased. For them, that meant a shift from reciprocal work for the household to commodified labour, and the income they earned from their wage labour was often kept by the women themselves. We should, however, stress that although many women worked, the income they generated was in many cases not enough to maintain themselves and their children in the event of divorce or widowhood.55

At the end of the fifteenth century and the beginning of the sixteenth century, two major changes took place: the arrival of large groups of

5I. Stillman, "The Non-Muslim Communities", pp. 199-202.

52. Shatzmiller, Her Day in Court, pp. I 50-I I.

53. For Goitein's explanation see A Mediterranean Society: The Jewish Communities of the Arab World, III: The Family, p. I35. For the economic position see Stillman, "The Non-Muslim Communities", pp. 208-209.

54. Shatzmiller, Her Day in Court, pp. 169-170.

55. Ruth Lamdan, "Jewish Women as Providers in the Generations following the Expulsion from Spain”, NASHIM: A Journal of Jewish Women's Studies and Gender Issues, I 3 (2007), pp. 49-67, 55; Cohen, Poverty and Charity, pp. I39-I 43. 
Sephardic immigrants from Spain and Portugal who had fled the Iberian peninsula in the face of the Inquisition, and integration - in the Egyptian case in I II7 - into the Ottoman Empire. Did those two developments influence women's work and the way it was perceived? They did bring economic advantages to the existing Jewish communities. The Sephardic migrants brought with them knowledge of banking, commerce, taxfarming, management of ports and custom houses, as well as trading networks and sometimes even capital. ${ }^{56}$ The expansion of the Ottoman Empire generated administrative state functions for Jews and strengthened their position in international trade, thereby also increasing the number of "job opportunities" for women.

The newcomers had their own specific views on women and work, however. Rabbis formed part of the Sephardic immigrant group that came to Egypt and some of them expressed their bewilderment at the rules and practices they encountered concerning women's work. Radbaz (an acronym of Rabbi David ben Solomon ibn (Abi) Zimra) was born in Spain in I 488 and settled in Egypt, becoming Chief Rabbi there in I 5 17. He was the author of more than 3,000 responsa as well as of several scholarly works, and in one of his responsa he stated:

Concerning the custom in Egypt, whereby the husband stipulates that the wife's handiwork belongs to her, and that he is responsible to pay her a yearly clothing allowance: Let us suppose that the wife is a good worker, and does not use up all her clothing allowance, but puts money aside, and becomes a money-lender, lending money to gentiles for interest, can the husband claim the usufruct thereof? [Answer:] The husband has no grounds for such a claim since [...] he has already waived any claim to her handiwork. Therefore he is not entitled to her handiwork or the usufruct thereof [...]. Moreover, since it is the custom here for a woman to use her earnings to help relatives or marry off daughters, or in any other way she see fit, and since the ketubab stipulates that her handiwork is hers, the husband, by marrying her, automatically endorses this custom. For when a man gets married, he takes on the local custom, even if it contravenes balakha. ${ }^{57}$

Joseph Caro (Toledo, I488-Safed, I 575), author of the famous great codification of Jewish law Shulchan Aruch, left Toledo for Istanbul and subsequently lived in Adrianople, Nikopol, and Salonika, to settle in Safed in I 536. Observing the position of the Musta'rab men (native Jews from Arab countries), he wrote indignantly: "that they are not entitled to their wives' property. Even if he [the husband] is in dire poverty, or languishing in jail, his wife does not let him use her property." ${ }^{8}$

56. Avigdor Levy, "Introduction", in idem (ed.), The Jews in the Ottoman Empire (Princeton, NJ, I994), pp. I-I 50, 24-28.

57. Radbaz, quoted in Lamdan, Separate People, p. I24.

58. Caro, quoted in ibid. 
For Radbaz and Caro, social customs concerning women, work, income, and possessions differed from the situation they were used to in Europe, although in their time Spain was still ruled by Islamic administrators. Their ideal consisted of women handing over their income to their husbands, who would have proprietorship of their wives' possessions. That state of affairs is comparable to the situation in medieval and early modern Christian Europe, where the ideal was still that men studied the Torah and women provided a large part of their family's income, although poverty often forced both men and women to work. 59 The responsa show us that in the sixteenth-century Arab-Islamic world it was still the custom for Jewish women to keep their own income.

The second development at the beginning of the sixteenth century, the integration of several countries with considerable Jewish communities into the Ottoman Empire, at first brought economic prosperity and increased job opportunities. After the expansions in the fifteenth and sixteenth centuries, however, the economic situation in the Ottoman Empire began to stagnate and went into decline in the first half of the seventeenth century; according to some, this was a natural and expected stage of adjustment after accelerated and widespread expansions in all spheres. $^{60}$ The stagnation affected the economic position of the Jews in the Ottoman Empire and in some cases specifically. European traders had discovered trading routes to the Americas, Asia, and Africa, and began overtaking traders in the Ottoman Empire. As a consequence of growing revenues from overseas trade, investment in new industries increased and European industries, such as the English textile industry, became serious competitors to Ottoman industries. Jewish traders in the Ottoman Empire who made their money from overseas trade lost much of their income, Jewish bankers lost clients, and Jewish government officials, such as tax-farmers, lost their jobs. ${ }^{61}$ Monetary problems made the economic and social situation even more tense, and although the crisis was not felt evenly throughout the Empire, we know that the wool trade in Salonika and Safed, which gave many Jews an income, collapsed. ${ }^{62}$ Did the crisis affect the economic position of women too?

59. Moshe Rosman, "The History of Jewish Women in Early Modern Poland: An Assessment", in ChaeRan Freeze et al. (eds), Polin, I8: Jewish Women in Eastern Europe (Oxford, 2005), pp. $25-56$.

60. Yaron Ben-Naeh, Jews in the Realm of the Sultans: Ottoman Jewish Society in the Seventeenth Century (Tübingen, 2008), p. 28.

61. Levy, "Introduction", The Jews in the Ottoman Empire, pp. 72-80, and Ben-Naeh, Jews in the Realm of the Sultans, pp. 28-32.

62. Ben-Naeh, Jews in the Realm of the Sultans, pp. 28-30; Levy, "Introduction", The Jeres in the Ottoman Empire, pp. 74-84. Levy notes that the Jewish community in Bursa was affected very much by the economic crisis, whereas the communities of Istanbul, Salonika, Edirne, Damascus, and Cairo still had a considerable number of wealthy members; p. 83 . 
For the seventeenth century we do not have a large set of analysed ketuboth - though we do find some that state that "her handiwork belongs to her". There is no large corpus of responsa which mention women and work explicitly, although there are texts which mention "her handiwork". There is the work of Rabbi Yehiel Bassan (I602-I625), who mentions a woman who earned a sizeable sum of money and kept her income for herself, causing the community to wonder whether her husband should pay more tax, considering that only heads of households paid tax. ${ }^{63}$ We know that during the Ottoman period women in general were legally and socially quite independent, certainly more so in practice than in legal theory. ${ }^{64}$ We know too that members of the Jewish communities in the Ottoman Empire continued to go to Muslim courts, for marital issues including divorce, as well as for cases involving inheritance, and that in spite of the sometimes stern disapproval of the rabbis. ${ }^{65}$ We may therefore conclude that in 1650 Jewish women still worked for wages and kept their income, and, although we have no information on their numbers, we know that they stayed more or less in the same professions throughout the late medieval, early modern period.

\section{WITH WHAT TYPES OF WORK DID JEWISH WOMEN EARN THEIR MONEY?}

The Cairo Geniza and later sources provide an insight into women's paid employment. The most important jobs were in manufacturing, especially textiles: spinning, silk weaving, textile dyeing, as well as embroidery, ${ }^{66}$ work for which they were trained on the job by other women. ${ }^{67}$

63. Lamdan, "Jewish Women as Providers". For the sixteenth-century ketuboth see p. 56; for the tax issue see p. 55 .

64. Joel L. Kraemer, "Spanish Ladies from the Cairo Geniza”, in: Alisa Meyuhas Ginio (ed.), Jews, Christians and Muslims in the Mediterranean World after 1492 (London [etc.], 2002), pp. $237-267,263-264$.

65. Joseph R. Hacker, "Jewish Autonomy in the Ottoman Empire: Its Scope and Limits. Jewish Courts from the Sixteenth to the Eighteenth Centuries", in Levy, The Jews in the Ottoman Empire, pp. 1 53-202, I 8 I-1 87; Aryeh Shmuelevitz, The Jews of the Ottoman Empire in the late Fifteenth and Sixteenth Centuries: Administrative, Economic, Legal and Social Relations as Reflected in the Responsa (Leiden, 1984), ch. 2. Najwa Al-Qattan, "Dhimmis in the Muslim Court: Legal Autonomy and Religious Discrimination", International Journal of Middle East Studies, 3I (1999), pp. 429-444, shows that Christian Copts too went to Muslim courts, especially to arrange marriage issues, and that Jewish and Christian women still went to Muslim courts to settle marital issues in eighteenth- and nineteenth-century Damascus.

66. Goitein, A Mediterranean Society: The Jewish Communities of the Arab World, I: Economic Foundations, p. I28.

67. Shatzmiller, Labour in the Medieval Islamic World, p. 360. See also Kraemer, "Spanish Ladies from the Cairo Geniza", who cites a woman who thanked her mother-in-law for the artisanship she learned, p. 259. 


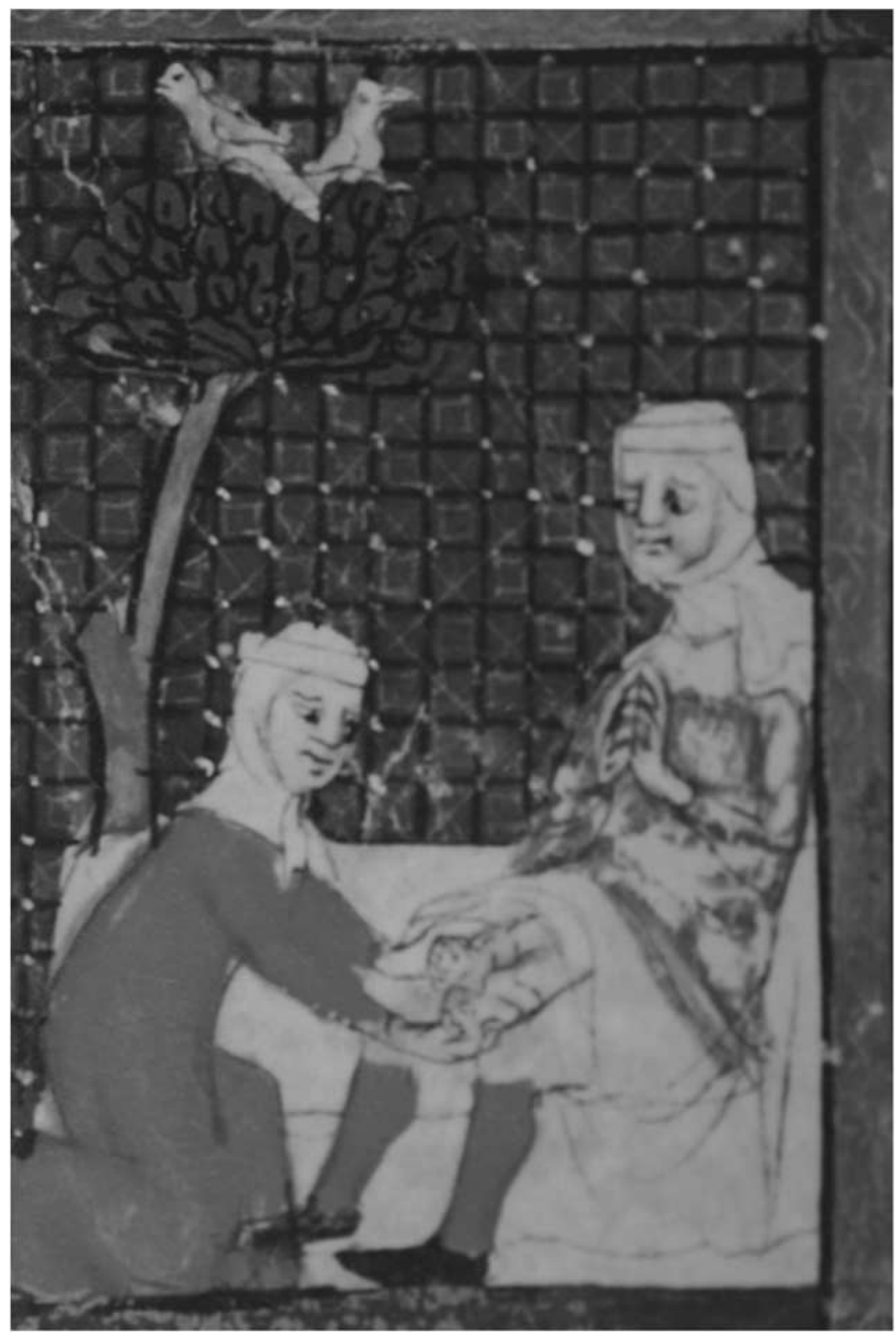

Figure 3. Midwife helping a woman to give birth, detail from the Sarajevo Haggadah (see Figure 2). National Museum of Bosnia and Herzegovina, Sarajevo. Haggadah, folio 9 verso (upper register, detail). Used with permission. 
Only a small number worked in food preparation. ${ }^{68}$ According to Shatzmiller, this might be explained by the prejudicial belief that menstruating women had a negative influence on the quality of food. ${ }^{69}$ Women worked in trade too: they sold their products, either directly or via brokers, and sold commodities such as perfumes or comestibles including wine, olive oil, and spices. $^{70}$ They worked as pedlars and in small-scale commerce, although some women were described as "shrewd businesswomen". ${ }^{71}$

A third sector where women worked was what we would now call the service sector: they might be doctors, practitioners who applied traditional medical knowledge and skills and who most likely learned the trade from their fathers or brothers. ${ }^{72}$ We find occultists, midwives, wet nurses, "bride combers", who not only combed brides' hair but also dressed them and organized part of the ceremony. There are references to women who washed the dead and earned money wailing as professional mourners, ${ }^{73}$ and there were mikveb (ritual bath) supervisors, astrologers, and fortune-tellers.

Women worked as teachers also. Domestic work, a source of income for many women in other parts of the world, was done by slaves in Arab society and so was not a remunerative occupation. ${ }^{74}$ The economic top layer was formed by women who worked as estate agents, selling properties or renting rooms in houses they owned, acting as moneylenders. ${ }^{75}$ In terms of status, that top layer would be followed by women working in trade and services, followed by women who earned their money in the textile industry, and finally by the pedlars.

In general, those trades as well as labour relations within the various economic branches remained unchanged between I 500 and I650. Ben-Naeh tells us, for the seventeenth century: "Female labor was a vital element in the chain of production, and women formed an integral part of the labor force in the textile industry, where they were paid lower wages than men." ${ }^{76}$

Women worked in all stages of what remained to a large extent a household industry: weaving, dyeing, and the final preparation of luxury fabrics and clothes. Women's work in trade from property dealing to peddling and services remained more or less unchanged. We do not know

68. Goitein, A Mediterranean Society: The Jerwish Communities of the Arab World, I: Economic Foundations, p. I29.

69. Shatzmiller, Labour in the Medieval Islamic World, p. 352.

70. Lamdan, Separate People, pp. I 18-1 I9.

71. Ibid., p. i 19 .

72. Shatzmiller, Labour in the Medieval Islamic World, p. 360.

73. Goitein, A Mediterranean Society: The Jewish Communities of the Arab World, I: Economic Foundations, pp. I27-I 29; Lamdan, Separate People, p. I 22.

74. Goitein, A Mediterranean Society: The Jewish Communities of the Arab World, I: Economic Foundations, p. I 29.

75. Lamdan, Separate People, pp. i 8-i 19.

76. Ben-Naeh, Jews in the Realm of the Sultans, p. 348. 
if the ratio of Jewish women who contributed to family income was greater than among other groups, but we do know that their presence in public places and their industriousness and skill were frequently mentioned by European travellers. ${ }^{77}$ That then brings us to another important question: Where did Jewish women work?

\section{WHERE DID JEWISH WOMEN WORK?}

According to Maimonides, Jewish women in Islamic countries were not supposed to leave the house more often than once or twice a month. How could they earn a living if they were confined to the four walls of their dwelling? One answer lies in their main trade of textile manufacture. Goitein states that it is not clear from the Geniza whether textile manufacturing took place in workshops employing groups of women or whether all the work was done individually and at home. ${ }^{78}$ Shatzmiller found no evidence for workshops for women, and therefore suggests that spinning, weaving, and embroidery were done at home. She found one reference to women congregating at one woman's home to spin flax and wool. ${ }^{79}$ We know that, although some women owned storehouses, workshops, and flour mills, they probably would not have worked in them themselves. ${ }^{8 \circ}$ Work was commissioned to the women in the textile industry by traders, brokers, or tax-farmers. Women workers most probably sold their finished products via brokers, who might be either Jewish or Muslim. ${ }^{8 \mathrm{I}}$ A solution for women going out to sell their products might have been the existence of special markets attended only by women. ${ }^{82}$ Commercial activity too was carried on from the home: there are several references to women doing their property dealing and moneylending from their residences, and even peddling seems to have been done from home. ${ }^{83}$

Unmarried women, widows, and divorcees had far more freedom to move about in public than married women did. Two famous documents, one court case and one will, illustrate that. The court case is either a late-eleventh or early twelfth-century one, dealing with a married woman whose husband went away on a journey for four years, leaving her with no means of supporting herself and their children. To earn a living the wife started teaching the Torah in the school of her brother, but when her husband came home he

77. Ibid., p. 349 .

78. Goitein, A Mediterranean Society: The Jewish Communities of the Arab World, I: Economic Foundations, p. I 28.

79. Shatzmiller, Labour in the Medieval Islamic World, p. 358; idem, Her Day in Court, p. I63.

80. Goitein, A Mediterranean Society: The Jewish Communities of the Arab World, III: The

Family, p. 326.

81. Shatzmiller, Her Day in Court, p. I63.

82. Idem, Labour in the Medieval Islamic World, p. 359.

83. Ibid., p. I89. 
complained about the inappropriateness of the situation. His wife had been accustomed to meet the fathers of her pupils and that was not in accordance with zniut rules. Furthermore, she was neglecting her duties as a wife since she had no time to cook and clean for him. Therefore he wanted to marry a second wife, which she forbade. Moses Maimonides, acting as the nagid of the Jewish community to whom this problem was presented, at first agreed with the husband: he could prevent his wife from teaching the children, but he could not take a second wife if his first one objected. After the man's wife had presented her side of the story, Maimonides's final decision was that he agreed wholeheartedly with her. Her husband should have provided his wife with money to maintain her and the children, although the husband was also entitled to prevent her from teaching, so the best thing for her to do was to "rebel", leave without the delayed instalment, and then he would be forced to divorce her: "She will be her own woman, [free to] teach whomever she pleases and do whatever she pleases." ${ }^{84}$ The other famous case concerns the will of Wusha, an unmarried woman banker and broker who had a child born out of wedlock. Her will shows that the economic freedom she enjoyed had made it possible for her to make a fortune during her lifetime. ${ }^{85}$

To return to our female traders: not all of them were unmarried, divorced, or widowed; we know some of them were married, ${ }^{86}$ so we must conclude that at least some violations of the social barriers must have taken place. The same goes for a number of the women who worked in the service sector: midwives, bride-combers, women washing the dead, and wailing women could hardly have worked from home. They must often have found themselves in all-female companies, but not always; for example, European travellers in the Ottoman Empire noticed Jewish women in Istanbul, Salonika, Cairo, Jerusalem, and Safed trading both indoors and in public markets. They worked trading mainly in silk, wool, and linen fabrics, jewellery, needlework, spices, olive oil, wine, vegetables, and various other items.

An early example of such a traveller is Rabbi Obadiah of Bertinoro, born in Italy in the second half of the fifteenth century. In I 486 he went to Jerusalem, and he wrote travel letters, from Egypt and Palestine among other places.About Cairo he writes that the Jewish families cooked at home only for the Sabbath, because men and women were busy the whole week and fuel (wood) was very expensive so they bought ready-made food in the bazaars. ${ }^{87}$ Unfortunately the rabbi does not mention what

84. Renée Levine Melammed, "He Said, She Said: A Woman Teacher in Twelfth-Century Cairo", AJS Revierw, 22 (1997), pp. 19-35, 27.

85. S.D. Goitein, “A Jewish Business Woman of the Eleventh Century”, The Jewish Quarterly Review, New Series, 75 (1967), pp. 225-242, 239.

86. Lamdan, Separate People, pp. I $25-\mathrm{I} 26$.

87. "Zwei Briefe Obadjahs aus Bartenuro aus dem Jahre 5258 und 5249, [I487-I488]", Jahrbuch für die Geschichte der Juden und der Judenthums (Leipzig, I863), pp. 193-270, 244. Many 
exactly kept both men and women so busy, but it was obvious that they were busy outside their homes or he would not have noticed it.

The mid-sixteenth century traveller Pierre Belon wrote that Jewish women acted as brokers for Muslim women and traded their products on the market, whereas George Sandys, travelling at the beginning of the seventeenth century, observed: "They are good workwomen, and can and will doe any thing for profit that is to be done by the art of a woman, and which sutes with the fashion of these countries." 88 For the Ottoman Empire in the seventeenth century, Ben-Naeh concludes that Jewish women did sell their goods in markets and streets, even if that contravened behavioural norms "despite repeated denunciations by preachers and teachers of ethical behaviour of any activity that entailed baring women's faces and hands and the fear they expressed of possible loss of innocence by female peddlers who made the rounds of the streets and the homes of Jewish and Gentile customers" ${ }^{89}$

The moral argument of opponents was supplemented by complaints from Jewish guilds about unfair competition from women pedlars..$^{\circ}$ Still, we must conclude with Ben-Naeh that "Both the general public and Islamic law exhibited a certain flexibility vis-à-vis the system of strict segregation". ${ }^{\text {I }}$

\section{TO CONCLUDE}

Ideas about Jewish women's work in the late medieval and early modern Arab-Islamic world were shaped by various laws and traditions as well as by socio-economic realities and necessities. One of those traditions was the ideal of the Jewish man studying his Torah, who through his study could understand God's will for the world and thereby would be performing the task valued the highest in Judaism - he did not have to bother too much about the family income because his wife would earn at least part of it. As a consequence of that ideal, which was in most cases no more than utopian dreaming, a Jewish woman could earn her wages and if necessary do so in the public sphere as long as the rules of zniut were respected. According to Jewish law, the wages a Jewish woman earned had to be surrendered to her husband, and a husband also had control of her dowry, which might very well have the potential to yield an income.

documents in the Cairo Geniza show us that food was indeed often bought ready to eat from the bazaars; Goitein, A Mediterranean Society: The Jewish Communities of the Arab World, I:

Economic Foundations, p. I30, and III: The Family, p. 341.

88. Both cited in Lamdan, "Jewish Women as Providers", p. 57.

89. Ben-Naeh, Jews in the Realm of the Sultans, p. 349.

90. Ibid.

91. Ibid., p. 369. 
The Jewish women Maimonides described in his Mishneb Torah lived in a Muslim society and so were of course influenced by Muslim ideas about women's work. Under Islamic law, a woman could keep her wages as they were seen as one of her property rights, and she kept full control of her own possessions, a rule that was upheld by Islamic courts. Women had more economic freedom under Islamic law, but Islamic ideals separated women's and men's worlds more than Jewish zniut rules did, making it hard for women to earn their money in the public domain.

From the ketuboth found in the Cairo Geniza we learn that after the twelfth century more and more Jewish women began to demand that they be allowed to keep their income, most probably as a consequence of the influence of Islamic law. That women could actually find paid work is explained by a previous transition in society from a predominantly slave labour market to a free wage labour market. In the textile industry, women took over the positions of slaves and the industry became partly, but not entirely, a "Jewish" industry. For a long time it was a booming industry, with many job opportunities for women. Work in the textile industry appealed to women because many of the tasks could be performed in their homes. Trading and services offered job opportunities for women, and a woman's social position might determine her occupation: the larger her dowry, the bigger the chance that she could become a successful property dealer or moneylender, although we also know of women who earned money from wage labour and saved up until they could establish themselves as moneylenders.

Legal restrictions on women working in the public domain were bypassed in several ways. Business transactions were done from the home and even peddling sometimes seems to have been done from the house. Some women used brokers to sell their products for them. We should keep in mind that in this particular Islamic environment it is important not just to see working women in relation to the contrast between the public and private spheres, but also in the context of the separate worlds of men and women. There were public spaces specifically designed for women's sole use, such as women's markets where traders and customers were female.

The tradition of women working for wages and keeping them continued throughout the late medieval, early modern period. When exiled rabbis from Spain settled in the Arab-Islamic world in the sixteenth century, they were somewhat unpleasantly surprised to see Jewish women keeping their incomes and taking control of their own possessions. Still, the rabbis had to accept those rules since the law of the kingdom was the law, and their power to prevent Jewish women (and men) from going to Muslim courts was at best limited.

As large parts of the Arab-Islamic world became integrated into the Ottoman Empire in the sixteenth century, Jewish women and men alike 
profited from the booming economy and state expansion. When that growth stagnated in the seventeenth century, economic opportunities diminished, but women continued to earn their money from the textile industry, trade, and services. We should conclude that there were differences between Jewish and Islamic rules and norms on the one hand and social practices in a quickly developing society on the other, leaving room for gainfully working women. 